\title{
Distribution of follicular growth, atresia and ovulation in the ovary of the domestic hen (Gallus domesticus) at different ages
}

\author{
D. Waddington and Marion A. Walker
}

AFRC Institute of Animal Physiology and Genetics Research, Edinburgh Research Station, Roslin, Midlothian EH25 9PS, U.K.

\begin{abstract}
Summary. Ovaries of laying hens of $14,18,30,45$ and 86 weeks of age were divided transversely into two or more distinct regions. Differences in follicular populations between these regions were observed. The central segments of the ovary in birds of 14 weeks of age produced most of the visible $(>0.5 \mathrm{mg})$ developing follicles $(P<0.01)$. This was a transient effect during ovarian maturation. In birds of 18 weeks of age, but not yet in lay, more follicles of $>8 \mathrm{~mm}$ in diameter were observed in the anterior part of the ovary than the posterior part $(P<0.05)$. Follicles of this size are almost certain to ovulate. The posterior segment of the ovary of birds of 30,45 and 86 weeks of age contained more follicles beginning the rapid growth phase, as measured by follicles of $1.4-1.8 \mathrm{~mm}$ in diameter, than did the anterior segment $(P<0.01)$. Higher levels of atresia in the posterior segment $(P<0.001)$ resulted in fewer follicles of $>8 \mathrm{~mm}$ $(P<0.001)$ and fewer post-ovulatory follicles than in the anterior segment. We conclude that most of the eggs produced during the hen's laying year must be from ovulations from the anterior part of the ovary.
\end{abstract}

Keywords: hen; age; ovary; follicular population distribution; ovulation

\section{Introduction}

The single functioning ovary of the domestic hen is a mushroom-shaped organ consisting of two major parts (Gilbert, 1979). It has a short stalk overlaying the abdominal aorta and vena cava. Ventral to the stalk is an extensive and complex convoluted germinal region, roughly oval in shape and longer along the anterior-posterior axis, within which follicles are exclusively confined. This stroma consists of an admixture of tissues derived from what were originally two separate areas, namely the true germinal epithelium of the ovary and the medullary tissue.

During development from hatching to maturity the ovary increases in size and complexity (Gilbert, 1979) and its surface is thrown into a series of 6-12 ridges interspersed with deep sulci (Prochazkova \& Komarek, 1970). These sulci run laterally and slightly diagonally across the surface of the ovary. Later, with continuing growth and follicular development, the sulci become obliterated leaving, in adult birds, a single narrower 'waist' formed from the lateral constriction of the stalk. The ovary is thus divided naturally along its length into two or more clearly defined segments or areas.

Because the laying hen is capable of producing one egg a day for many months, all stages of follicular development and regression of the post-ovulatory follicle are present simultaneously during the reproductive period. Follicular maturation is a long process lasting about 14 days during which time a follicle increases in diameter from about 1 to $40 \mathrm{~mm}$ (Gilbert et al., 1983; Perry et al., 1983). On any given day, more than 10 follicles of $2-3 \mathrm{~mm}$ diameter may be present, but at most 1 or 2 of these are destined to ovulate. The remainder become atretic. It is not known whether a 
specific follicular factor favours survival or whether atresia is randomly spread throughout the ovary. This study investigates whether there are differences in atresia and ovulation between the naturally occurring divisions of the ovary described earlier. Ovaries were examined during the phase of rapid development around the time of sexual maturity, when possible differences might become established, and also from birds which had been in lay for over a year to look for any changes which might be related to the decline in laying performance with age. The work was undertaken as a preliminary study in the modelling of follicular growth, atresia and ovulation in the hen's ovary.

\section{Materials and Methods}

Animals and groups. Birds were of the ISA Brown strain obtained at 1 day of age from a commercial supplier. At 12 weeks of age they were transferred from rearing pens to individual battery cages. Increased lighting and layers rations were introduced before lay in compliance with the breeder's recommendations. Food and water were available ad libitum. About 200 birds were obtained and those required for the experiments were selected from this pool.

Five groups of birds were chosen. The 20 birds for Group 1 were selected at an age of 14 weeks when follicular growth would be expected to have just started. Group 2 (26 birds) was selected at 17-20 weeks of age. Individual birds were chosen because they had not yet laid but their external appearance indicated that they were close to sexual maturation. Their ovaries were expected to contain many developing follicles and to have almost a complete complement of hierarchical follicles $>8 \mathrm{~mm}$ in diameter. The 20 birds in Group 3 were taken at about 30 weeks of age when the birds were in peak production. Group 4 contained 18 mature birds of 45 weeks of age when egg production was just beginning to decline. Group 5 , of 20 older birds ( 86 weeks of age), was used when egg production was expected to be poorer.

All birds were killed by an i.v. overdose of pentobarbitone sodium (Expiral: Ceva, Southampton, U.K.) and the ovaries were exposed. The numbers of post-ovulatory follicles (if present) and normal and atretic follicles $>8 \mathrm{~mm}$ in diameter in each segment of the ovary were recorded. Normal, freshly atretic and grossly atretic follicles $\leqslant 8 \mathrm{~mm}$ in diameter in each segment were identified (Gilbert et al., 1985), removed and placed in formalin for subsequent measurement of size (diameter) (Gilbert et al., 1982). Numbers of these follicles in 5 size ranges were obtained by passing them through a series of sieves of decreasing mesh size. The mesh sizes were $5,3 \cdot 15,2.36,1.8$ and $1.4 \mathrm{~mm}$. In Group 1 birds ( 14 weeks) few follicles were present and these were weighed. The ovary minus follicles of $>1 \mathrm{~mm}$ diameter was divided into segments and weighed.

Not all the data for birds in Groups 1 and 2 are presented here because the ovaries of these birds contained variable numbers of ridges or segments. In Group 1, the ovaries of 16 birds had 7 segments (Group la) and those of 4 birds had 6 segments (Group lb). These last 4 birds are included in the data presented in Table 1, but excluded from those in Table 2 because they cannot be analysed in the same way. The second group cover the transitional stage in the change from several segments in the ovary to only two. Only data from the 11 birds with 'two-segment' ovaries are presented here (Group 2a). The other 15 birds had ovaries containing more segments, and were presumed to be at earlier stages in the transition.

Statistical analyses. The number of normal follicles in each segment and the segment weights for birds in Group 1 were analysed after combining some of the data (see Fig. 1). The outer 4 segments (1, 2, 6 and 7 for Group 1a; $1,2,5$ and 6 for Group Ib) and the middle 2 or 3 segments (3, 4 and 5 for Group la; 3 and 4 for Group lb) were grouped together. The difference between the average per segment for the middle and outer segments was calculated for each ovary. A pooled estimate of error, weighted by number of observations in Groups $1 \mathrm{a}$ and $1 \mathrm{~b}$, was then used in Student's $t$ tests on $18 \mathrm{~d}$.f. of whether differences between the middle and outer segments were compatible with a value of zero. Possible relationships between the weight of ovarian tissue in the grouped middle and outer segments and the corresponding number, maximum sizè or rate of atresia (no. of atretic follicles/no. of atretic + normal follicles) of follicles were assessed by comparing the numbers of ovaries in each cell of a $2 \times 2$ classification for each of these 3 traits for Group la. Ovaries were classified as $\mathrm{M}$ (middle) $>\mathrm{O}$ (outer) or $\mathrm{M}<\mathrm{O}$ for combined segment weight and for each trait. When there were tied values, ovaries were omitted. The presence of an interaction in these $2 \times 2$ tables, assessed by a Fisher exact test, indicates some relationship. If there was no interaction the data were pooled, ignoring segment weight, and a binomial test was used to compare the middle and outer groups of segments.

Similar $2 \times 2$ analyses of the data from Groups $2 a$ and 3 are presented. The ovaries of birds in these groups contained only 2 segments, anterior and posterior, and this classification replaces the middle outer one used for Group 1 (see Fig. 1).

Groups 3, 4 and 5 were also analysed together as the within-bird level of a split-plot analysis of variance. Most of the data are counts or proportions, but they do not follow Poisson or binomial distributions. They cannot be normally distributed, except as an approximation. Each observation in an age $\times$ segment subgroup was weighted inversely by the estimated subgroup variance, as these variances differed between subgroups of different ages. The average standard deviations of all the subgroups are presented in Tables 4 and 5 as a guide to variability. 


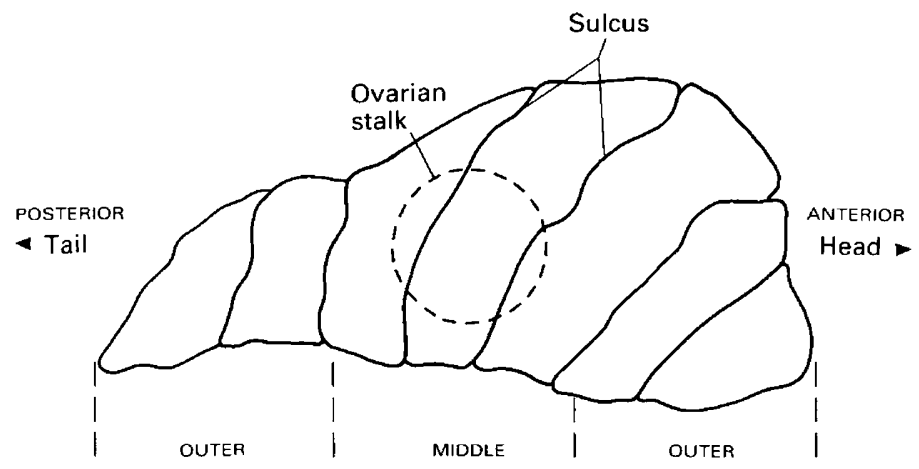

Fig. 1. Schematic caudal view of the surface of an ovary with 6 sulci in birds 14-18 weeks of age. As birds approach sexual maturity the sulci are obliterated and the ovary broadens, but it is restricted at the centre by the attachment of the stalk. This narrowing gives rise to the posterior-anterior division in mature birds.

\section{Results}

Group 1 (14-week-old birds)

Mean segment weights and numbers of normal follicles produced per segment are given for individual segments in Table 1. The middle segments tended to be heavier than the outside ones (M-O: Group 1a $=13.3 \mathrm{mg}$, s.e. $=4.4, P<0.01$; Group $1 \mathrm{~b}=34.6 \mathrm{mg}$, s.e. $=9.97, P<0.01$ ) and to produce more normal follicles per segment $(\mathrm{M}-\mathrm{O}$ : Group $1 \mathrm{a}=1 \cdot 24$, s.e. $=0 \cdot 24, P<0 \cdot 001$; Group $1 \mathrm{~b}=2 \cdot 13$, s.e. $=0 \cdot 55, P<0 \cdot 01$ ) for Groups $1 \mathrm{a}$ and $1 \mathrm{~b}$.

Table 1. Mean ovary segment weights and numbers of follicles $>0.5 \mathrm{mg}$ for the 16 birds with 7-segment ovaries (Group 1a) and the 4 birds with 6-segment ovaries (Group 1 b) aged 14 weeks

\begin{tabular}{lllllllll}
\hline & & \multicolumn{7}{c}{ Segment number } \\
\cline { 3 - 9 } & & $\begin{array}{c}1 \\
\text { (anterior) }\end{array}$ & 3 & 4 & 5 & 6 & 7 \\
(posterior) & \\
\hline Ovary segment & Group 1a & 56 & 74 & 80 & 79 & 80 & 73 & 63 \\
weight (mg) & Group 1b & 66 & 100 & 124 & 113 & 87 & 81 & - \\
No. of normal & Group 1a & 0.6 & $1 \cdot 1$ & 2.3 & $2 \cdot 2$ & $2 \cdot 4$ & 1.5 & 0.9 \\
follicles & Group 1b & $\mathbf{0 . 3}$ & $3 \cdot 0$ & $4 \cdot 8$ & $2 \cdot 5$ & $1 \cdot 0$ & 1.8 & - \\
\hline
\end{tabular}

For birds in Group la the weights of ovarian tissue in the combined segments $\mathrm{M}$ and $\mathrm{O}$ were roughly similar. This was not the case for Group $1 \mathrm{~b}$, and so these ovaries were omitted from the $2 \times 2$ classifications presented in Table 2 . There is no evidence that the larger numbers of follicles observed in the middle of the ovary are a consequence of more ovarian tissue. Atresia and maximum follicle size were similar in both groups of segments.

\section{Group $2 a$ (18-week-old birds)}

Comparisons of the anterior and posterior segments for follicle numbers $\leqslant 8$ and $>8 \mathrm{~mm}$ and rates of atresia for follicles $\leqslant 8 \mathrm{~mm}$ are given in the first part of Table 3. On average, the larger 
Table 2. Comparison of the middle three $(\mathrm{M})$ with the outer four $(\mathrm{O})$ segments of the ovary for the numbers of normal follicles, proportion of atretic to total numbers of follicles and the maximum follicle size for the ovaries of 16 birds aged 14 weeks (Group la)

\begin{tabular}{|c|c|c|c|c|c|c|}
\hline & \multicolumn{2}{|c|}{$\begin{array}{l}\text { No. of } \\
\text { normal } \\
\text { follicles }\end{array}$} & \multicolumn{2}{|c|}{$\begin{array}{l}\text { Proportion of } \\
\text { atretic/total } \\
\text { follicles }\end{array}$} & \multicolumn{2}{|c|}{$\begin{array}{l}\text { Maximum } \\
\text { follicle } \\
\text { size }\end{array}$} \\
\hline & $M>0$ & $\mathrm{M}<\mathrm{O}$ & $\mathrm{M}>\mathrm{O}$ & $\mathrm{M}<\mathrm{O}$ & $\mathrm{M}>\mathrm{O}$ & $M<O$ \\
\hline \multicolumn{7}{|l|}{ Segment weight } \\
\hline$M>0$ & 3 & 0 & 3 & 0 & 4 & 0 \\
\hline $\mathbf{M}<\mathbf{O}$ & 10 & 1 & 4 & 5 & 7 & 5 \\
\hline \multicolumn{7}{|l|}{$\begin{array}{l}\text { Probability of no segment } \\
\text { weight } \times \text { segment group } \\
\text { interaction }\end{array}$} \\
\hline Pooled counts & 13 & 1 & 7 & 5 & 11 & 5 \\
\hline $\begin{array}{l}\text { Probability of no difference } \\
\text { between segments }\end{array}$ & \multicolumn{2}{|c|}{$<0.01$} & \multicolumn{2}{|c|}{$>0.05$} & \multicolumn{2}{|c|}{$>0.05$} \\
\hline
\end{tabular}

Table 3. Comparison of the anterior (A) with the posterior (P) segment of the ovary for the number of normal follicles $\leqslant 8 \mathrm{~mm}$ in diameter, the proportion of atretic/total follicles of $\leqslant 8 \mathrm{~mm}$ and the number of normal follicles of $>8 \mathrm{~mm}$ in diameter for the ovaries of 11 birds aged 18 weeks (Group 2a), and 19 birds aged 30 weeks (Group 3)

\begin{tabular}{|c|c|c|c|c|c|c|}
\hline & \multicolumn{2}{|c|}{$\begin{array}{l}\text { No. of normal } \\
\text { follicles } 1.4-8 \mathrm{~mm}\end{array}$} & \multicolumn{2}{|c|}{$\begin{array}{l}\text { Proportion of } \\
\text { atretic/total } \\
\text { follicles } \leqslant 8 \mathrm{~mm}\end{array}$} & \multicolumn{2}{|c|}{$\begin{array}{l}\text { No. of normal } \\
\text { follicles }>8 \mathrm{~mm}\end{array}$} \\
\hline & $\mathrm{A}>\mathrm{P}$ & $\mathbf{A}<\mathbf{P}$ & $\mathrm{A}>\mathrm{P}$ & $\mathbf{A}<\mathbf{P}$ & $\mathbf{A}>\mathbf{P}$ & $\mathbf{A}<\mathbf{P}$ \\
\hline \multicolumn{7}{|l|}{ Group 2a } \\
\hline $\mathbf{A}>\mathbf{P}$ & 5 & 1 & 3 & 3 & 4 & 1 \\
\hline $\mathbf{A}<\mathbf{P}$ & 0 & 5 & 2 & 3 & 4 & 0 \\
\hline $\begin{array}{l}\text { Probability of no segment } \\
\text { weight } \times \text { segment position } \\
\text { interaction }\end{array}$ & \multirow{2}{*}{\multicolumn{2}{|c|}{$<+0 .+$}} & \multicolumn{2}{|c|}{$>0.05$} & \multicolumn{2}{|c|}{$>0.05$} \\
\hline Pooled counts & & & 5 & 6 & 8 & 1 \\
\hline $\begin{array}{l}\text { Probability of no difference between } \\
\text { segments }\end{array}$ & \multicolumn{2}{|c|}{$-\dagger$} & \multicolumn{2}{|c|}{$>0.05$} & \multicolumn{2}{|c|}{$<0.05$} \\
\hline \multicolumn{7}{|l|}{$\begin{array}{l}\text { Group } 3 \\
\quad \text { Segment weight }\end{array}$} \\
\hline $\mathrm{A}>\mathrm{P}$ & 5 & 5 & 1 & 9 & 8 & 1 \\
\hline $\mathrm{A}<\mathrm{P}$ & 2 & 6 & 1 & 8 & 7 & 1 \\
\hline $\begin{array}{l}\text { Probability of no segment } \\
\text { weight } \times \text { segment position } \\
\text { interaction }\end{array}$ & \multicolumn{2}{|c|}{$>0.05$} & \multicolumn{2}{|c|}{$>0.05$} & \multicolumn{2}{|c|}{$>0.05$} \\
\hline Pooled counts & 7 & 11 & 2 & 17 & 15 & 2 \\
\hline $\begin{array}{l}\text { Probability of no difference between } \\
\text { segments }\end{array}$ & \multicolumn{2}{|c|}{$>0.05$} & \multicolumn{2}{|c|}{$<0.001$} & \multicolumn{2}{|c|}{$<0.01$} \\
\hline
\end{tabular}

†Pooling not appropriate in the presence of an interaction.

segment in an ovary produced more follicles of $\leqslant 8 \mathrm{~mm}(P<0.01)$. Rates of atresia did not appear to be affected by segment weight or segment position but, none the less, the anterior part of the ovary produced more follicles of $>8 \mathrm{~mm}$ in diameter $(P<0.05)$. 
Groups 3, 4 and 5 (laying birds of 30, 45 and 86 weeks of age)

In contrast to Group 2 birds, ovary segment weight did not appear to influence the numbers of normal follicles $\leqslant 8 \mathrm{~mm}$ for birds at peak of lay ( 30 weeks) (Table 3 ), nor was there a preponderance of these follicles in the anterior or posterior segments. However, there was an increase in the rate of atresia of follicles of $\leqslant 8 \mathrm{~mm}$ in diameter in the posterior part of the ovary $(P<0.001)$, leading to the production of fewer follicles of $>8 \mathrm{~mm}$ in diameter $(P<0.01$; Table 3$)$.

Means of variables in Table 3, ovary segment weight and numbers of post-ovulatory follicles for Groups 3, 4 and 5 are presented in Table 4. For birds in Groups 4 and 5 the anterior segment of the ovary was almost always heavier than the posterior segment and so segment weight was used as a covariate for follicle numbers and rates of atresia. The posterior part of the ovary produced more normal follicles of $\leqslant 8 \mathrm{~mm}$ in diameter for all ages, but this excess of follicles was greater in Groups 4 and $5(P<0.05)$. A higher rate of atresia for follicles $\leqslant 8 \mathrm{~mm}$ in diameter in the posterior segment $(P<0.001)$ resulted in fewer follicles of $>8 \mathrm{~mm}$ in diameter being present $(P<0.001)$. The decline in numbers of follicles of $>8 \mathrm{~mm}$ with age was very similar for both parts of the ovary. Differences between segments in numbers of follicles of $>8 \mathrm{~mm}$ in diameter should be reflected, albeit historically, in lower numbers of post-ovulatory follicles in the posterior area of the ovary. This was the case, except that the deficit became more marked with age $(P<0.001)$.

Table 4. Means of ovary segment weight, numbers and rates of atresia of follicles of $\leqslant 8 \mathrm{~mm}$ in diameter and numbers of follicles $>8 \mathrm{~mm}$ and post-ovulatory follicles for the anterior (A) and posterior (P) segments of the ovary of birds of 30 (Group 3, N=20), 45 (Group 4, N=18) and 86 (Group 5, N=20) weeks of age, with some statistical comparisons and estimates (s.e. in parentheses)

\begin{tabular}{|c|c|c|c|c|c|c|}
\hline & & $\begin{array}{c}\text { Ovary } \\
\text { segment } \\
\text { weight }(\mathrm{g})\end{array}$ & $\begin{array}{l}\text { Normal } \\
\text { follicles } \\
1 \cdot 4-8 \mathrm{~mm}\end{array}$ & $\begin{array}{l}\text { Proportion of } \\
\text { atretic/total } \\
\text { follicles } \\
1.4-8 \mathrm{~mm}\end{array}$ & $\begin{array}{l}\text { Normal } \\
\text { follicles } \\
>8 \mathrm{~mm}\end{array}$ & $\begin{array}{l}\text { Post-ovulatory } \\
\text { follicles }\end{array}$ \\
\hline \multicolumn{7}{|l|}{ Means } \\
\hline Group 3 & $\begin{array}{l}\mathrm{A} \\
\mathrm{P}\end{array}$ & $\begin{array}{l}0.89 \\
0.85\end{array}$ & $\begin{array}{l}15 \cdot 0 \\
17 \cdot 4\end{array}$ & $\begin{array}{l}0 \cdot 19 \\
0.34\end{array}$ & $\begin{array}{l}5 \cdot 45 \\
2 \cdot 25\end{array}$ & $\begin{array}{l}6 \cdot 10 \\
3 \cdot 75\end{array}$ \\
\hline Group 4 & $\begin{array}{l}\mathrm{A} \\
\mathrm{P}\end{array}$ & $\begin{array}{l}1.44 \\
1.07\end{array}$ & $\begin{array}{l}19 \cdot 7 \\
24 \cdot 6\end{array}$ & $\begin{array}{l}0 \cdot 17 \\
0 \cdot 30\end{array}$ & $\begin{array}{l}4 \cdot 72 \\
0 \cdot 67\end{array}$ & $\begin{array}{l}6.44 \\
1.56\end{array}$ \\
\hline Group 5 & $\begin{array}{l}\mathbf{A} \\
\mathbf{P}\end{array}$ & $\begin{array}{l}1.69 \\
1.24\end{array}$ & $\begin{array}{l}23 \cdot 6 \\
29 \cdot 5\end{array}$ & $\begin{array}{l}0.39 \\
0.49\end{array}$ & $\begin{array}{l}4 \cdot 40 \\
0 \cdot 70\end{array}$ & $\begin{array}{l}8.35 \\
0.75\end{array}$ \\
\hline Average s.d. & & $0 \cdot 25$ & $8 \cdot 1$ & $0 \cdot 11$ & $1 \cdot 25$ & $2 \cdot 04$ \\
\hline $\begin{array}{l}\text { Statistical comparisons } \\
\text { Age } \times \text { segment interaction } \\
\left(\mathrm{F}_{2.47}\right) \\
\text { Posterior-anterior }\end{array}$ & & 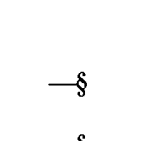 & $3 \cdot 88^{*}$ & 0.22 & 0.58 & $11 \cdot 79^{* * *}$ \\
\hline $\begin{array}{l}\text { difference } \dagger \\
\text { Slope of segment weight }\end{array}$ & & $-\S$ & $-\ddagger$ & $0 \cdot 14(0.02)^{* * *}$ & $-3.43(0.27)^{* * *}$ & $-\ddagger$ \\
\hline covariate $†$ & & $-\S$ & $10 \cdot 8(3 \cdot 3)^{* *}$ & $0.04(0.05)$ & $0.78(0.50)$ & $1.01(1.06)$ \\
\hline
\end{tabular}

${ }^{*} P<0.05 ; * * P<0.01 ; * * P<0.001$.

$\nmid$ Ratios of the estimates to their standard errors are approximately distributed as a Student's $t$ distribution on 47 d.f. $\$$ No difference given due to the presence of an interaction.

$\S$ No analysis performed.

The numbers of normal follicles of $\leqslant 8 \mathrm{~mm}$ in diameter are broken down into different size classes in Table 5. Formalin preservation increases follicular size (Gilbert et al., 1982), and so the size distributions presented are all biased upwards. It is not known whether the bias is influenced by the age of the bird. Posterior-anterior segment differences were only present in follicles of 
$<3.5 \mathrm{~mm}$ in diameter. From this it can be seen that the increased atresia in the posterior part of the ovary gradually reduced the higher numbers of follicles observed there at earlier stages of growth to give approximately equal numbers of the larger follicles in both segments. The excess of normal follicles of $1.4-1.8 \mathrm{~mm}$ in the posterior part of the ovary $(P<0.01)$ indicates that more follicles were starting growth in this area.

Table 5. Means of numbers of follicles in 5 size ranges from 1.4 to $8 \mathrm{~mm}$ for the anterior (A) and posterior (P) segments of the ovary of birds of 30 (Group 3, N=20), 45 (Group 4, N=18) and 86 (Group $5, \mathrm{~N}=20$ ) weeks of age, with some statistical comparisons and estimates (s.e. in parentheses)

\begin{tabular}{|c|c|c|c|c|c|c|}
\hline & & \multicolumn{5}{|c|}{ Size range } \\
\hline & & $1.4-1.8 \mathrm{~mm}$ & $1 \cdot 8-2.36 \mathrm{~mm}$ & $2.36-3.15 \mathrm{~mm}$ & $3 \cdot 15-5 \mathrm{~mm}$ & $5-8 \mathrm{~mm}$ \\
\hline \multicolumn{7}{|l|}{ Means } \\
\hline Group 3 & $\begin{array}{l}\mathrm{A} \\
\mathrm{P}\end{array}$ & $\begin{array}{l}1 \cdot 15 \\
2 \cdot 00\end{array}$ & $\begin{array}{l}4 \cdot 20 \\
4 \cdot 60\end{array}$ & $\begin{array}{l}3.90 \\
4.95\end{array}$ & $\begin{array}{l}3.85 \\
3.75\end{array}$ & $\begin{array}{l}1 \cdot 90 \\
2 \cdot 10\end{array}$ \\
\hline Group 4 & $\begin{array}{l}\mathrm{A} \\
\mathrm{P}\end{array}$ & $\begin{array}{l}2 \cdot 78 \\
4 \cdot 11\end{array}$ & $\begin{array}{l}4 \cdot 50 \\
7 \cdot 33\end{array}$ & $\begin{array}{l}4.94 \\
5 \cdot 39\end{array}$ & $\begin{array}{l}4.94 \\
5 \cdot 50\end{array}$ & $\begin{array}{l}2 \cdot 56 \\
2 \cdot 28\end{array}$ \\
\hline Group 5 & $\begin{array}{l}\mathrm{A} \\
\mathrm{P}\end{array}$ & $\begin{array}{l}11 \cdot 35 \\
16.90\end{array}$ & $\begin{array}{l}3.65 \\
4.90\end{array}$ & $\begin{array}{l}2 \cdot 75 \\
3 \cdot 65\end{array}$ & $\begin{array}{l}3 \cdot 75 \\
2 \cdot 70\end{array}$ & $\begin{array}{l}2 \cdot 10 \\
1 \cdot 35\end{array}$ \\
\hline Average s.d. & & $4 \cdot 00$ & $2 \cdot 71$ & $2 \cdot 18$ & $2 \cdot 21$ & 1.63 \\
\hline $\begin{array}{l}\text { Statistical comparisons } \\
\text { Age } \times \text { segment interaction } \\
\left(\mathrm{F}_{2,47}\right) \\
\text { Posterior-anterior difference } \dagger \\
\text { Slope of segment weight } \\
\text { covariate }\end{array}$ & & $\begin{array}{c}2.51 \\
1.07(0.37)^{* *} \\
-0.41(1.00)\end{array}$ & $\begin{array}{c}3.59^{*} \\
\frac{\ddagger}{1 \cdot 7 !(1.45)}\end{array}$ & $\begin{array}{c}0.60 \\
1.39(0.39)^{* * *} \\
2.52(0.93)^{* *}\end{array}$ & $\begin{array}{c}1.79 \\
0.33(0 \cdot 35) \\
2.98(0 \cdot 82)^{* * *}\end{array}$ & $\begin{array}{c}0.28 \\
0.04(0.38)\end{array}$ \\
\hline
\end{tabular}

${ }^{*} P<0.05 ;{ }^{* *} P<0.01 ;{ }^{* * *} P<0.001$.

$\dagger$ Ratios of the estimates to their standard errors are approximately distributed as a Student's $t$ distribution on 47 d.f. $\ddagger$ No difference given due to the presence of an interaction.

\section{Discussion}

Even relatively crude divisions of the ovary have served to demonstrate that the development of follicles is not a process which is uniform throughout the ovary, and also changes with age. At 14 weeks of age most of the developing follicles were found in the central segments of the ovary. In mature birds no such central dominance in follicle production was observed. Although this could be due to the earlier development of the vascular system near the stalk of the rapidly growing ovary, no direct evidence is available.

The patterns of follicular growth, atresia and ovulation were very similar in adult birds of all ages. The posterior part of the ovary had higher numbers of follicles in the early stages of rapid growth $(1-3 \mathrm{~mm})$, higher rates of atresia and fewer follicles of $>8 \mathrm{~mm}$ in diameter and postovulatory follicles. Follicles of $>8 \mathrm{~mm}$ in diameter in young birds of this strain are almost certain to ovulate (Gilbert et al., 1983). This is less certain for older birds (Waddington et al., 1985). In this study only 3 laying birds, one of each age, had a single atretic follicle of $>8 \mathrm{~mm}$ in diameter. The rest had none. For Group 5 birds this observation may be related to their rate of lay of $60 \%$, which is unusually high for birds of this age. The preponderance of follicles of $>8 \mathrm{~mm}$ in diameter in the anterior segment was established even before birds came into lay. The average numbers in birds of 18 weeks of age were 4.6 in the anterior and $2 \cdot 3$ in the posterior segment, i.e. two-thirds were found in the anterior part. This is smaller than the observed proportions for the birds in lay. Thus, the hen 
achieves high rates of ovulation with only one functional ovary, and most ovulable follicles arise from the anterior segment of this ovary while the posterior segment remains relatively dormant.

The decreases in numbers of large ( $>8 \mathrm{~mm}$ diam.) yellow follicles with age followed very similar patterns for both halves of the ovary. Further studies would be needed to examine whether the decline in egg production as birds age could be linked to relative changes in the production of ovulable follicles within the two distinct ovarian segments. The excess of post-ovulatory follicles in the anterior part of the ovary increased with age, contrasting with the consistent difference in follicles of $>8 \mathrm{~mm}$ in diameter. The ratio of post-ovulatory follicles to normal follicles of $>8 \mathrm{~mm}$ in the anterior segment of the ovary increased with age, suggesting that post-ovulatory follicles may be absorbed more slowly in older birds.

In mice higher ovulation rates have been observed in the right ovary than in the left (see Wiebold \& Becker, 1987) and proposed mechanisms have included improved blood supply or a larger number of follicles available for growth. Extrapolation of our observations on follicles of $1.4-1.8 \mathrm{~mm}$ suggests that the second of these possibilities is not the cause of an increased ovulation rate in the anterior part of the mature hen's ovary. Nalbandov \& Jones (1949) and Armstrong (1987) have suggested a survival advantage arising from increased blood supply for follicles growing on the stalks of large $(>8 \mathrm{~mm}$ ) follicles. Poorer blood supply to the posterior part of the ovary could lead to decreased follicular stimulation by gonadotrophins resulting in higher levels of atresia. The observed increase in the number of follicles starting growth in this region could then be explained by decreased quantities of some inhibitory substance in the blood. Inhibitor substances are known to exist in the mammalian ovary (Franchimont \& Channing, 1981; Goodman \& Hodgen, 1982), and they could be present also in the bird's ovary.

The results presented here reflect the influence of the local ovarian environment on follicular growth and ovulation. Previous work may require reassessment when it rests on the assumption of a homogeneous population of growing follicles. For example, Gilbert et al. (1983) have suggested that the balance between initiation of rapid growth and subsequent atresia determines the number of follicles of $>8 \mathrm{~mm}$ in diameter available for ovulation, and hence egg production. Also, Hocking et al. (1987) have shown an inverse relationship between the number of follicles of $>8 \mathrm{~mm}$ in diameter destined to ovulate and the rate of atresia in small follicles $2-5 \mathrm{~mm}$ in diameter in laying birds and broiler breeder hens. These are obviously oversimplified statements when the initiation of rapid growth, atresia and ovulation are spatially heterogeneous processes within the ovary. Similarly, studies relating plasma hormone concentrations to changes in reproductive performance may oversimplify by missing local ovarian changes in folliculogenesis which bring about observed differences. Conversely, it is possible that measurements of follicular characteristics such as receptor populations or hormone production could also be subject to this extra source of spatial variability, which may then mask real differences between the ovaries of birds given different experimental treatments.

We thank Dr A. B. Gilbert for support and advice throughout this work.

\section{References}

Armstrong, D.G. (1987) Ornithene decarboxylase activity in small ovarian follicles from the laying hen (Gallus domesticus). A comparison of follicles from several regions of the ovary. J. Endocr. 112, 183-187.

Franchimont, P. \& Channing, C.P. (eds) (1981) Intragonadal Regulation of Reproduction. Academic Press, London.

Gilbert, A.B. (1979) Female genital organs. In Form and Function in Birds, vol. 1, pp. 237-360. Eds A. S. King \& J. McLelland. Academic Press, London

Gilbert, A.B., Hardie, M.A. \& Perry, M.M. (1982) The relationship between the weight and diameter of the small ovarian follicles of the domestic hen (Gallus domesticus). IRCS Med. Sci. 10, 571.

Gilbert, A.B., Perry, M.M., Waddington, D. \& Hardie, M.A. (1983) Role of atresia in establishing the follicular hierarchy in the ovary of the domestic hen (Gallus domesticus). J. Reprod. Fert. 69, 221-227.

Gilbert, A.B., Perry, M.M., Walker, M.A. \& Waddington, D. (1985) Identification of atresia in small ovarian follicles of the domestic hen (Gallus domesticus). IRCS Med. Sci. 13, 732-733. 
Goodman, A.L. \& Hodgen, G.D. (1982) The ovarian triad of the primate menstrual cycle. Recent Prog. Horm. Res. 39, 1-67.

Hocking, P.M., Gilbert, A.B., Walker, M. \& Waddington, D. (1987) Ovarian follicular structure of white leghorns fed ad libitum and dwarf and normal broiler breeders fed ad libitum or restricted to point of lay. Br. Poult. Sci. 28, 493-506.

Nalbandov, A.V. \& Jones, M.F. (1949) The blood vascular system of the chicken ovary. Am. J. Anat. 85, 347-378.

Perry, M.M., Waddington, D., Gilbert, A.B. \& Hardie, M.A. (1983) Growth rates of the small yolky follicles in the ovary of the domestic fowl. IRCS Med.Sci.11, 979-980.
Prochazkova, E. \& Komarek, V. (1970) Growth of the zona vasculosa and zona parenchymatosa in postnatal development of the ovary in the chicken. Acta vet., Brno 39, 3-10.

Waddington, D., Perry, M.M., Gilbert, A.B. \& Hardie, M.W. (1985) Follicular growth and atresia in the ovaries of hens (Gallus domesticus) with diminished egg production rates. $J$. Reprod. Fert. 74, 399-405.

Weibold, J.L. \& Becker, W.C. (1987) Inequality in function of the left and right ovaries and uterine horns of the mouse. J. Reprod. Fert. 79, 125-134.

Received 18 January 1988 